\title{
Pemanfaatan Teknologi Informasi di Perpustakaan
}

\author{
Fahrizandi \\ Institut Agama Islam Negeri Pontianak \\ email: fahrizandii@gmail.com
}

\begin{abstract}
The title of this article is the use of information technology in the library, this paper aims to explain what are the reasons for the use of information technology and the constraints of the use of information technology in libraries and what are the competencies of librarians in the information technology era. The results of the analysis of the literature, it is important to take advantage of information technology in the library. The reasons for using information technology are easier catalog search, users can search catalogs from outside the library, better information services, easily edit bibliographic information, make more space in the library, and increase library images. Constraints in applying information technology, namely the loyal librarian of conventional services, the low quality of human resources, and the lack of information technology tools. Librarians in the era of information technology must have the capabilities of soft competency and hard competency.
\end{abstract}

Keywords: library; information technology; competency

\begin{abstract}
Abstrak
Judul artikel ini adalah pemanfaatan teknologi informasi di Perpustakaan, tulis ini bertujuan untuk menjelaskan apa alasan pemanfaatan teknologi informasi dan kendala pemanfaatan teknologi informasi di perpustakaan serta apa saja kompetensi pustakawan era teknologi informasi. Hasil analisis dari literatur, maka penting memanfatkan teknologi informasi di perpustakaan. Alasan pemanfaatan teknologi informasi yaitu pencarian katalog lebih mudah, pengguna dapat mencari katalog dari luar perpustakaan, layanan informasi lebih baik, mudah mengedit informasi bibliografi, membuat lebih banyak ruang di perpustakaan, dan image perpustakaan meningkat. Kendala menerapkan teknologi informasi, yaitu Pustakawan loyal layanan konvesional, rendahnya kualitas sumber daya manusia, dan kurangnya perangkat teknologi informasi. Pustakawan era teknologi informasi harus memiliki kemampuan yaitu soft competency dan hard competency.
\end{abstract}

Kata kunci: Perpustakaan; Teknologi Informasi; Kompetensi

\section{A. PENDAHULUAN}

Teknologi informasi lahir pada tahun 1947, sejalan dengan munculnya komputer sebagai komponen utama. Masa teknologi setelah masa yang mengeksploitasi materi sekitar 50.000 tahun sebelum masehi sampai 
pada abad ke-18 dan diikuti dengan masa teknologi yang mengeksploitasi energi dari abad ke-18 hingga abad ke-20 yaitu sekitar tahun 1947an. Perkembangan teknologi informasi yang kemudian dihubungkan dengan perpustakaan karena melihat kebutuhan akses sumber informasi atau dengan kata lain perpustakaan yang didukung oleh teknologi informasi maka muncullah bentuk perpustakaan yang disebut dengan Perpustakaan Digital. (Koswara, 1998, p. 60).

Munculnya teknologi informasi tatkala penggunaan komputer mulai menyebar. Perkembangan teknologi informasi yang begitu pesat telah dirasakan berdampak pada sebagian besar aspek kehidupan manusia baik secara langsung maupun tidak langsung. Perkembangan teknologi informasi akibat adanya revolusi industri yang mengalami beberapa tahapan yang secara umum dapat diidentifikasi setiap perkembangannya.

Abad informasi mulai muncul didahului dengan sebuah revolusi yang disebut dengan revolusi industri 1.0. revolusi ini ditandai dengan dimulainya pengembangan mesin uap. Kemudian revolusi industri 2.0 terjadi pada Perang Dunia 1 dengan ditandainya proses produksi alat-alat perang. Proses pemproduksian peralatan perang tersebut dilakukan dengan mendirikan pabrik-pabrik. Abad industri mulai berakhir pada masa revolusi industri 3.0. Dengan berakhirnya masa revolusi industri 3.0 maka kemudian dimulainya masa abad informasi. Revolusi industri 4.0 ditandai dengan segalanya digital, segalanya dalam genggaman tangan, dalam smartphone dan yang terkait. Revolusi industri 4.0 inilah yang kemudian mengubah peradaban manusia termasuk pada peran pustakawan dalam melayani pemustaka di perpustakaan. (Antologi Kajian dalam bidang Ilmu Perpustakaan dan Informasi : Filosofi, Teori, dan Praktik, 2019, p. 112)

Industry 4.0 telah digunakan sebagai deskripsi umum untuk proses produksi baru yang sepenuhnya otomatis melalui teknologi, dan perangkat berkomunikasi secara otonom satu sama lain disepanjang kegiatan.(Ustundag \& Cevikcan, 2018, p. 123)

Kehadiran perangkat teknologi informasi telah mengubah pola kerja termasuk di perpustakaan, yang semula pola kerja konvensional dan sederhana menuntut berbasis otomasi dan lebih mutakhir. Dampak lain dari teknologi informasi yaitu meledaknya beragam jenis media dan sumber informasi yang tersedia atau yang akan disediakan di perpustakaan demi memenuhi harapan yang tinggi dari pemustaka terhadap ketersedian informasi. 
Sekarang, teknologi informasi telah mendapatkan reputasi untuk memberikan semua informasi yang orang inginkan, pemustaka dapat mengakses katalog perpustakaan, database online, dan sumber informasi yang tak terhitung banyaknya dari mana saja dan kapan saja.

Lee Rainie, Direktur Proyek Internet \& Kehidupan Amerika, menerbitkan laporannya tentang tren perkembangan saat ini di perpustakaan umum di Amerika Serikat, yaitu membaca buku elektronik sedang tumbuh, tetapi buku cetak masih mendominasi dunia membaca. Namun, 69\% membaca buku cetak, hanya $4 \%$ pembaca 'e-book saja'. Sebagian besar pembaca e-book juga membaca buku cetak. (Yang \& Li, 2016, p. 9)

Implementasi teknologi informasi perpustakaan tidak dapat ditolak kehadirannya, maka profesionalisme pustakawan dipertaruhkan. Pemustaka yang sudah terbiasa dimanjakan oleh fasilitas-fasilitas teknologi tentu akan menuntut pula mereka akan mendapatkan layanan berbasis teknologi informasi yang dapat membantu mereka dalam memperoleh informasi yang diperlukan. (Nugrohoadhi, 2013, p. 112)

Memang diakui, kehadiran teknologi informasi memberikan tawaran kemudahan-kemudaha dalam melakukan kegiatan di perpustakaan, namun tidak semua pekerjaan dapat tergantikan sepenuhnya oleh teknologi informasi. Dasar inilah, yang menimbulkan pro dan kontra untuk memanfaatkan teknologi informasi di perpustakaan. Sebagian perpustakaan menerima teknologi sebagai media untuk pengembangan dalam mengelola perpustakaan yang lebih baik, hal ini terlihat dengan menyiapkan berbagai perangkat teknologi informasi, menyiapkan keahlian pustakawan dalam bidang teknologi. Namun di sisi lain, masih adanya rasa kekhawatiran atas kehadiran teknologi informasi merasa menggeser pekerja rutin perpustakaan, belum tersedia perangkat teknologi, bahkan tidak memiliki sumber daya manusia yang menguasai teknologi informasi.

Dengan mengggunakan analisis dari literatur, tulisan ini bertujuan membahas tentang alasan perlunya pemanfaatan teknologi informasi di perpustakaan dan kendala-kendala pemanfaatan teknologi informasi di perpustakaan, serta kompetensi pustakawan yang diperlukan pada era teknologi informasi. 


\section{B. HASIL DAN PEMBAHASAN}

\section{Pengertian Teknologi Informasi}

Istilah dari akar kata 'teknologi" berasal dari bahasa Yunani 'tekhne', sedangkan 'logy' berasal dari bahasa Yunani 'logia / logos'. 'Tekhnologia' diterjemahkan sebagai 'perawatan sistematis'. Teknologi bukan hanya disiplin akademis atau sains dalam dirinya sendiri. Ini juga merupakan serangkaian sistem, proses atau metode yang telah dikembangkan untuk melakukan serangkaian kegiatan yang lebih efisien atau lebih efektif. Aspek kunci dari teknologi yaitu pertama, teknologi adalah kumpulan pengetahuan yang terus berubah dan berkembang. aset berharga, tidak berwujud, yang dapat membuat perbedaan antara keberhasilan dan kegagalan bagi banyak organisasi. Kedua, teknologi adalah metode yang berkaitan dengan pemahaman, pengembangan, implementasi dan penggunaan sistem yang bertujuan untuk memecahkan masalah. Tujuan dasarnya adalah kegunaan atau kegunaan. Ketiga, teknologi adalah sistem yang telah dikembangkan untuk melayani tujuan tertentu. Inti dari sistem teknologi adalah proses transformasi. (Baker, 2004, p. 17)

Tampaknya istilah ini memiliki arti berbeda untuk orang yang berbeda. Definisi ini juga bervariasi tergantung pada berbagai bidang subjek. Menurut Burkhardt dalam (Yang \& Li, 2016, p. 2), teknologi yang muncul dalam konteks perpustakaan, dapat berupa alat apa pun yang digunakan dengan cara baru untuk melayani pengguna Anda. Walaupun demikian teknologi yang muncul belum tentu merupakan penemuan baru, banyak teknologi yang lebih tua sedang diciptakan kembali dan digunakan secara kreatif untuk tujuan modern.

Teknologi informasi adalah teknologi yang digunakan untuk menyimpan, menghasilkan, mengolah, serta menyebarkan informasi. (Sulistyo-Basuki, 1993, p. 87)

Sedangkan, teknologi dalam bidang perpustakaan dibatasi pada teknologi pengadaan, pengolahan, penyimpanan, dan penyebaran berbagai jenis informasi dengan memanfaatkan komputer dan telekomunikasi. (Koswara, 1998, p. 164)

Perpustakaan digital mulai dikenal dan disebut masyarakat sekal berkembangannya teknologi informasi, perpustakaan dan teknologi informasi. Perpustakaan Digital lalu menjadi suatu alternatif yang dapat dilakukan perpustakaan untuk meningkatkan layanan perpustakaannya. Dengan sistem digital ini, perpustakaan mampu memformat informasi yang 
tersedia dari format tercetak menjadi format elektronis atau digital sehingga koleksi yang disediakan dapat digunakan secara lebih efisien dan efektif.

Sejalan dengan perkembangan teknologi informasi (TI), hal ini ditandai dengan perkembangan komputerisasi basis-data katalog (metadata) dan media penyimpanan konten-nya (full text). Perkembangan dari mulai perpustakaan tradisional menjadi semi modern menuju modern, dan kemudian berkembang menjadi perpustakaan digital (hybrid) sampai akhirnya menuju era perpustakaan virtual (Mulyadi, 2016, p. 11)

Dari beberapa pengertian teknologi dapat dipakami sebagai suatu disiplin ilmu, metode untuk memecahkan masalah, dan sistem melayani tujuan tertentu. Sedangkan teknologi informasi dalam konteks perpustakaan adalah pemanfatan komputer dan telekomunikasi dalam melakukan kegiatan tugas dan fungsi perpustakaan.

\section{Alasan Pemanfaatan Teknologi Informasi}

Setiap perpustakaan mempunyai alasan yang berbeda dalam pemanfaatan teknologi informasi. Alasan pemanfaatan teknologi indormasi di perpustakaan, antara lain: 1) Pencarian katalog akan lebih mudah; 2) Pengguna akan dapat mencari katalog perpustakaan dari luar perpustakaan; 3) Memberikan layanan informasi yang lebih baik; 4) Mudah untuk mengedit dan memperbarui informasi bibliografi; 4) Membuat lebih banyak ruang di perpustakaan; dan 6) image perpustakaan Anda akan meningkat. (MacKellar, 2008, p. 257)

Pencarian katalog akan lebih mudah - perpustakaan konvensional kehadiran katalog tercetak sangat vital untuk menunjukan letak lokasi koleksi yang dimiliki satu perpustakaan, saat peneluran koleksi pemustaka dapat menelusuri lewat katalog pengarang, judul dan subjek. Katalog tercetak harus disusun berdasarkan abjad pengarang, judul dan subjek, sehingga memudahkan untuk menggunakan katalog menemukan koleksi di rak, biasanya perpustakaan memiliki lemari katalog yang terbatas, katalog mudah lepas dan hingga ketika banyak yang mengunakan. Kehadiran katalog elektronik atau online public accees catalog maka pencarian lokasi koleksi sangat mudah, hanya dengan mengetik kata tertentu, tidah harus berurutan, maka informasi tentang lokasi koleksi dengan cepat diketahui.

Pengguna dapat mencari katalog perpustakaan dari luar perpustakaan - katalog elektronik sangat memungkin untuk pertukaran data bibliografi katalog terutama perpustakan yang memiliki perangkat teknologi informasi yang sama, setelah adanya penyeragaman data bibliografi yang 
dilakukan secara elektronik. Pertukaran dan penyeragaman data bibliogradi elektronik sangat memungkin setelah terjadinya kerja sama antar perpustakaan. Dengan perangkat teknologi informasi data koleksi dari berbagai jenis perpustakaan yang berbeda dapat diakses pada salah data base katalog pada perpustakaan tertentu.

Memberikan layanan informasi yang lebih baik - pemanfaatan teknologi informasi di perpustakan akan memberikan kemudahan dalam memberikan layanan baik yang berkaitan dengan layanan publik seperti layanan penelusaran inforamsi, sirkulasi, referensi. Kemudahan layanan teknis seperti kegiatan pengadaan, pengolahan, penentuan klasifikasi, tajuk subyek, katalogisasi. Kemudahan juga dalam memberikan layanan administrasi seperti persuratan, pendataan sarana dan prasarana perpustakaan, pelaporan. Layanan akan lebih efektif dan efisien.

Mudah untuk mengedit dan memperbarui informasi bibliografi koleksi yang dimiliki perpustakaan harus terdata secara berkala yang memuat informasi bibliografi secara benar. Pluktuasi perkembangan koleksi memungkin adanya perubahan data termasuk kelengkapan data bibliograsi suatu koleksi, dengan pemanfaatan teknologi informasi kegiatan pengeditan dan pembaharuan data sangat mudah dilakukan.

Membuat lebih banyak ruang di perpustakaan - pemanfaatan teknologi informasi dapat mengatasi keterbatasan ruang, dan keterbatasan jumlah SDM. Jika pemanfaatan teknologi informasi di perpustakaan secara penuh segala perangkat atau perabot manual dapat diganti dengan beberapa ketersedian komputer, bahkan ruang semakin terasa luas jika koleksi tercetak telah digitalisasi, rak koleksi berkurang, lemari katalog berkurang.

Image perpustakaan Anda akan meningkat - kehadiran teknologi informasi di perpustakaan memberikan citra baik bagi pengguna, karena teknologi memberikan sesuatu hal baru terutama aspek tampilan menarik, layanan yang cepat, dan kemudahan dalam proses penelusuran informasi.

Menurut Koswara dalam bukunya memaparkan beberapa alasan mengapa teknologi harus diterima di perpustakaan yaitu pertama, tuntutan terhadap jumlah dan mutu layanan perpustakaan; kedua, tuntutan terhadap penggunaan koleksi bersama (resources sharing); ketiga, kebutuhan untuk mengefektifitaskan sumber daya manusia; keempat, tuntutan terhadap efisiensi waktu; kelima, keragaman informasi yang dikelola dan keenam, kebutuhan akan ketepatan layanan informasi. (Koswara, 1998, pp. 157-160) 
Lebih lanjut, alasan perpustakaan menggunakan komputer untuk melaksanakan fungsi dan tugas perpustakaan sebagai berikut: pertama, mengatur informasi (in-house information) serta mengusahakannya agar informasi tersebut dapat ditemubalikkan; kedua, mengakses pangkalan data ekstern berisi infomasi diterbitkan atau semi diterbitkan; ketiga, bertambanya beban kerja; keempat, perlunya efiensi, menghemat waktu, staf, biaya.; kelima, jasa dan fungsi baru; keenam, jaringan kerja dan koperasi; dan ketujuh, citra baik perpustakaan. (Sulistyo-Basuki, 1993, p. 93)

\section{Pertimbangan Memilih Perangkat}

Dalam menentukan pemanfatan teknologi informasi masi disesuaikan dengan ukuran perpustakaan, jenis perpustakaan, pendanaan, kebutuhan perpustakaan, dan filosofi lembaga mereka, tugas pustakawan sehingga teknologi berdaya tepat guna.

Beberapa pertimbangan dalam pemilihan perangkat keras komputer, instalasi, dan pemecahan masalah, yaitu :

a. Pemilihan perangkat lunak, instalasi, dan dukungan

b. Administrasi lokal dan / atau jaringan luas tanggung jawab keamanan

c. Dukungan Internet, termasuk router, server proxy, dan konfigurasi firewall

d. Keamanan dan stabilitas lingkungan komputasi publik

e. Desain dan pemeliharaan halaman web

f. Fungsi help desk umum

g. Penghubung vendor database

h. Pemilihan dan implementasi sumber daya elektronik

i. Pemrograman skrip asli

j. Digitalisasi, pengarsipan, dan katalogisasi koleksi dokumen, audio, dan video

k. Dukungan dan desain intranet

1. Pelatihan staf dan teknologi pelindung

m. Pemeliharaan dan migrasi sistem perpustakaan terintegrasi (ILS), peningkatan, dan pelatihan

n. Pengembangan dan pemrograman basis data 
o. Manajemen proyek

p. Membuat dokumentasi teknis

q. Membuat RFP dan spesifikasi sistem yang diperlukan untuk vendor Sistem

r. Memiliki anggaran dan manajemen (Gordon, 2003, pp. 7-8)

Sedangkan, dari aspek arsitektur teknologi informasi perpustakaan berbasis web yang terdiri dari tiga lapisan utama: (1) klien Web; (2) Server web; dan (3) repositori data. (Yang \& Li, 2016, p. 3)

Lapisan pertama, klien web (juga disebut ujung depan), desktop, HDTV, notebook, smartphone, dan tablet telah banyak digunakan sebagai media informasi utama yang digunakan pengguna untuk mengakses dan menemukan informasi di era digital. Sebagai terobosan teknologi terbaru, komputer yang dapat dipakai yang diwakili oleh Google Glass dan Apple iWatch juga telah muncul sebagai klien web perintis baru di era pasca-PC.

Lapisan kedua, server web digunakan untuk menanggapi permintaan klien web dan mengirim kembali halaman web yang membutuhkan melalui Hypertext Transfer Protocol (HTTP). Server web adalah komputer yang berfungsi sebagai tempat penyimpanan untuk halaman web, termasuk tautan web untuk layanan jejaring sosial utama. Server web kemudian akan mengambil halaman web yang dibutuhkan dan mengirimkannya kembali ke browser web yang diinstal pada perangkat komputasi klien web, seperti notebook atau smartphone.

Pada lapisan ketiga, repositori data, basis data elektronik, perpustakaan digital, basis pengetahuan, alat penyimpanan lain, dan (OPAC) berbasis web untuk mendukung sumber daya perpustakaan dan layanan.

\section{Penerapan Teknologi Informasi}

Pengaruh dari penerapan teknologi informasi, perpustakaan dapat dibedakan menjadi tiga macam bentuk, yaitu bentuk perpustakaan tradisional, bentuk perpustakaan terotomasi, dan bentuk perpustakaan digital. (Supriyanto \& Muhsin, 2008, p. 18)

Perpustakaan tradisional yaitu perpustakaan yang memiliki koleksi tercetak yang disusun di rak dengan seluruh kegiatan layanan pemustaka, pengolahan, dan administrasi proses pencatatan dilakukan sepenuhnya secara manual oleh petugas. 
Perpustakaan terotomasi yaitu perpustakaan yang memiliki koleksi tercetak yang disusun di rak dengan seluruh kegiatan layanan pemustaka, pengolahan, dan administrasi proses pencatatan dilakukan dengan bantuan komputer.

Perpustakaan digital yaitu perpustakaan yang memiliki koleksi digital berupa $e$-jurnal, $e$-book, $\mathrm{CD}$ audio maupun video untuk membacanya mengunakan bantuan perangkat komputer atau perangkat lainya, seluruh kegiatan layanan pemustaka, layanan teknis, dan administrasi proses pencatatan dilakukan dengan bantuan komputer.

Jenis-jenis penerapan teknologi informasi dalam bidang layanan perpustakaan dapat dilakukan dalam beberapa hal yaitu : -) layanan sirkulasi. Dengan menerapkan teknologi informasi dalam layanan sirkulasi maka banyak hal yang dapat dilakukan perpustakaan diantaranya adalah layanan peminjaman, layanan pengembalian, statistik pengguna, dan administrasi keanggotaan. Selain itu dapat juga dilakukan silang layanan antar perpustakaan yang lebih mudah dilakukan apabila teknologi informasi sudah menjadi bagian dari layanan sirkulasi ini. Teknologi saat ini sudah memungkinkan adanya self-services dalam layanan sirkulasi melalui fasilitas barcoding dan RFID (Radio Frequency Identification). Penerapan teknologi komunikasi pun sudah mulai digunakan seperti penggunaan SMS, Faksimili dan Internet. -) Layanan Referensi \& Hasil-hasil Penelitian. Penerapan teknologi informasi dalam layanan referensi dan hasil-hasil penelitian dapat dilihat dari tersedianya akses untuk menelusuri sumber-sumber referensi elektronik/digital dan bahan pustaka lainnya melalui kamus elektronik, direktori elektronik, peta elektronik, hasil penelitian dalam bentuk digital, dan lain-lain. -) Layanan Journal / Majalah / Berkala. Pengguna layanan journal, majalah, berkala akan sangat terbantu apabila perpustakaan mampu menyediakan kemudahan dalam akses ke dalam journal-journal elektronik, baik itu yang diakses dari database lokal, global maupun yang tersedia dalam format Compact Disk dan Disket. -) Layanan Multimedia/Audio-Visual. Layanan multimedia/audio-visual yang dulu lebih dikenal sebagai layanan "non book material" adalah layanan yang secara langsung bersentuhan dengan teknologi informasi. Pada layanan ini pengguna dapat memanfaatkan teknologi informasi dalam bentuk kaset video, kaset audio, microfilm, microfische, compact disk, laser disk, DVD, home movie, home theatre, dll. layanan ini juga memungkinkan adanya media interaktif yang dapat dimanfaatkan pengguna untuk melakukan pembelajaran, dsbnya. hal lain yang perlu diperhatikan dalam layanan perpustakaan adalah pengguna yang mempunyai keterbatasan, seperti penglihatan yang kurang, buta, pendengaran 
yang kurang dan ketidakmampuan lainnya. layanan multimedia/audio-visual memungkinkan perpustakaan dapat memberikan pelayanan kepada para pengguna dengan kriteria ini. sebagai contoh dari bentuk penerapan teknologi untuk itu adalah audible e-books, digital audio books, info eyes (virtual reference), braille, dsbnya. -) Layanan Internet \& Computer Station. Internet saat ini menjadi "bintang" dalam TI. Orang sudah tidak asing lagi untuk menggunakan internet dalam kehidupannya. Untuk itu mau tidak mau perpustakaanpun harus dapat memberikan layanan melalui media ini. Melalui media web perpustakaan memberikan informasi dan layanan kepada penggunanya. Selain itu perpustakaan juga dapat menyediakan akses internet baik menggunakan computer station maupun WIFI / Access Point yang dapat digunakan pengguna sebagai bagian dari layanan yang diberikan oleh perpustakaan. Pustakawan dan perpustakaan juga bisa menggunakan fasiltas web-conferencing untuk memberikan layanan secara online kepada pengguna perpustakaan. web-conferencing ini dapat juga dimanfaatkan oleh bagian layanan informasi dan referensi. OPAC atau Online Catalog merupakan bagian penting dalam sebuah perpustakaan, untuk itu perpustakaan perlu menyediakan akses yang lebih luas baik itu melalui jaringan lokal, intranet maupun internet. -) Keamanan. Teknologi informasi juga dapat digunakan sebagai alat untuk memberikan kenyamanan dan keamanan dalam perpustakaan. Melalui fasilitas semacam gate keep (Zuhrah, 2011, p. 42)

Dengan demikian beberapa hal yang dapat dilakukan dengan teknologi informasi adalah layanan sirkulasi, layanan jurnal/majalah/terbitan berkala, layanan multimedia, layanan akses internet, kenyamanan dan keamanan dalam perpustakaan.

Sedangkan, di perpustakaan sering mengalami kendala-kendala untuk memanfaatkan teknologi informasi untuk membantu kegiatan melaksankan tugas dan fungsi perpustakaan. Adapun, kendala pemanfaatan teknologi informasi di perpustakaan dipengaruhi oleh faktor internal dan faktor eksternal.

Ditinjau dari faktor internal antara lain :

a. Pustakawan loyal dengan layanan konvesional - pustakawan merasa nyaman dan puas dengan pekerjaan rutinitas yang ada diperpustakaan, merasa seluruh pekerjaan dapat diselasaikan dengan baik tanpa harus memakai bantuan teknologi

b. Rendahnya kualitas sumber daya manusia dalam penguasan teknologi informasi - kualitas sdm salah satu faktor berkualitasnya layanan perpustakaan, pustakawan telah memiliki 
keahlian dalam bidang kepustakawan tetapi tidak untuk keahlian penguasaan dibidang teknologi informai baik menyangkut pengetahuan jenis-jenis perangkat teknologi informasi maupun cara pengoperasian teknologi informasi.

Sementara dari faktor ekternal, yaitu kurangnya perangkat teknologi informasi - berbicara tentang teknologi informasi maka harus didukung ketersediaan perangkat teknologi (hardware), rasanya tidak mungkin pemanfaatan teknologi informasi di perpustakaan tanpa dilengkapi perangkat keras (hardware) dan perangkat lunak (software). Berkaitan dengan perangkat teknologi perlu ketersediaan anggaran yang cukup.

\section{Kompetensi Pustakawan}

Dalam bidang perpustakaan, pustakawan harus memiliki kompetensi, yaitu soft competency dan hard competency (Antologi Kajian dalam bidang Ilmu Perpustakaan dan Informasi: Filosofi, Teori, dan Praktik, 2019, p. 110)

Pertama, tipe "soft competency". Tipe kompetensi ini berkaitan erat dengan kemampuan untuk mengatur proses pekerjaan dan berinteraksi dengan orang lain. Yang termasuk dalam soft competency di antaranya adalah kemampuan manajerial, kemampuan memimpin (kepemimpinan), kemampuan komunikasi, dan kemampuan membangun hubungan dengan orang lain (interpersonal relation).

Kedua, tipe "hard competency". Tipe kompetensi kedua tersebut berkaitan dengan kemampuan fungsional atau teknis suatu pekerjaan. Dengan kata lain, kompetensi ini berkaitan dengan seluk beluk teknis yang berkaitan dengan pekerjaan yang ditekuni. Contoh hard competency di bidang perpustakaan antara lain kemampuan untuk mengklasir, mengkatalog, mengindek, membuat abstrak, input data, melayani pemustaka, melakukan penelusuran informasi dsb. (Antologi Kajian dalam bidang Ilmu Perpustakaan dan Informasi : Filosofi, Teori, dan Praktik, 2019, p. 110)

Selanjutnya, era industri 4.0 tidak terkecuali perpustakaan mengharuskan semua karyawan, bahkan pekerja dengan pekerjaan berketerampilan rendah, untuk memiliki keterampilan teknologi informasi dan komunikasi. Namun, Industry 4.0 membutuhkan perangkat keterampilan karyawan lebih dari keterampilan inti (core skills. memang, untuk keberhasilan pelaksanaan keterampilan keras (hard-skills), karyawan harus memiliki keterampilan lunak (soft-skills) seperti kolaborasi, komunikasi, dan otonomi untuk dapat melaksanakan pekerjaan. Dalam dunia kerja yang 
kompleks saat ini, kemampuan beradaptasi menjadi kemampuan terpenting bagi karyawan, karyawan perlu membiasakan diri untuk belajar terusmenerus, tidak hanya dalam profesi mereka sendiri tetapi dalam sudut pandang yang lebih luas melalui interdisipliner perspektif. Selain itu, kapasitas inovatif sangat penting untuk keunggulan kompetitif organisasi. Lebih lanjut, menurut prediksi World Economic Forum, pada tahun 2020, tenaga kerja masa depan diharapkan memiliki sebagian besar kemampuan kognitif (52\%), keterampilan sistem (42\%), dan keterampilan pemecahan masalah rumit $(40 \%)$. Selain keterampilan itu, pekerja dituntut memiliki keterampilan dasar untuk teknologi informasi dan komunikasi (TIK). Sejalan dengan peningkatan otomatisasi dan digitalisasi proses kerja, organisasi lebih bergantung pada karyawan dengan spesialisasi TIK. Keterampilan TIK menjadi kebutuhan bagi semua karyawan bahkan bagi pekerja yang memiliki pekerjaan dengan keterampilan rendah. (Ustundag \& Cevikcan, 2018, p. 127)

\section{KESIMPULAN}

Pemanfaatan teknologi informasi sangat relevan untuk memberikan layanan terbaik di perpustakaan demi memenuhi tingginya keinginan pemustaka akan informasi. Dengan adanya teknologi akan mengubah paradigma perpustakan yang konvensional menuju yang lebih mutakhir, tetapi tidak selamanya pemanfaatan teknologi menggunakan perangkat yang canggih, teknologi dapat berupa alat apa pun yang digunakan dengan cara baru dan kreatif untuk melayani pemustaka. Dalam pemanfaatan teknologi informasi di perpustakaan harus memiliki perangkat keras (hardware) dan perangkat lunak (software), serta tersedia pustakawan kompeten yang memiliki kemampuan soft-skills maupun hard-skill.

\section{DAFTAR RUJUKAN}

Antologi Kajian Dalam Bidang Ilmu Perpustakaan Dan Informasi : Filosofi, Teori, Dan Praktik. (2019). Jakarta: Ikatan Sarjana Ilmu Perpustakaan Dan Informasi Indonesia.

Baker, D. (2004). The Strategic Management Of Technology: A Guide For Library And Information Services. Oxford: Chandos Publishing. Https://Doi.Org/10.1108/Eb054013

Gordon, R. S. (2003). The Accidental Systems Librarian. New Jersey: Information Today.

Koswara, E. (Ed.). (1998). Dinamika Informasi Dalam Era Global. Bandung: Remaja Rosdakarya. 
Mackellar, P. H. (2008). The Accidental Librarian. New Jersey: Information Today.

Mulyadi. (2016). Pengelolaan Perpustakaan Digital. Palembang: Noer Fikri.

Nugrohoadhi, A. (2013). Menakar Peranan Pustakawan Dalam Implementasi Teknologi Informasi Di Perpustakaan. Khizanah Al-Hikmah, 1(2), 101114. Retrieved From Http://Journal.UinAlauddin.Ac.Id/Index.Php/Khizanah-Al-Hikmah/Article/View/34/14

Sulistyo-Basuki. (1993). Pengantar Ilmu Perpustakaan. Jakarta: Gramedia Pustaka Utama.

Supriyanto, W., \& Muhsin, A. (2008). Teknologi Informasi Perpustakaan. Yogyakarta: Kanisius.

Ustundag, A., \& Cevikcan, E. (2018). Industry 4.0: Managing The Digital Transformation. Switzerland: Springer Nature. Https://Doi.Org/10.1007/978-3-319-57870-5

Yang, S. Q., \& Li, L. (2016). Emerging Technologies For Librarians: A Practical Approach To Innovation. Practical Art Of Motion Picture Sound. Amsterdam: Elsevier.

Zuhrah, F. (2011). Pentingnya Teknologi Informasi Dalam Meningkatkan Pelayanan Di Perpustakaan. Jurnal Iqra', 5(1), 40-49. 